\title{
Modeling Void Ratio Influences on Shigella Transport in Heterogeneous Grave Depositions
}

\author{
Nwaoburu $\mathrm{AO}^{1}$ and Eluozo $\mathrm{SN}^{2 *}$ \\ ${ }^{1}$ Department of Mathematics, Faculty of Science, Rivers State University, Nigeria \\ ${ }^{2}$ Department of Civil, College of Engineering Gregory University, Nigeria
}

*Corresponding author: Eluozo SN, Department of Civil College of Engineering Gregory University Uturu Abia State, Nigeria.

Received Date: April 24, 2019

Published Date: May 07, 2019

\begin{abstract}
The study examined the transport of Shigella in heterogeneous gravel formation, this is to monitored the migration of Shigella in two different ways, monitoring of the contaminants at vertical direction were increase in in concentration with respect to change in depth and monitoring the concentration influenced by variation of gravel porosities, these two dimension were carried out, it was observed that the transport of Shigella in vertical direction experienced exponential growth rate to the optimum level recorded at ninety meters, this can be attributed to deposition of micronutrients that may increase the population rate of Shigella, this increase the concentration of the contaminant to the optimum depth, while that of porosity influences experienced variation of soil consolidation, decrease in porosity where high consolidation is observed experienced high concentration of Shigella, while increase in soil porosity decrease the concentration of Shigella at different location as observed from the study, the predictive values were subjected to model validation, and both parameters developed best fits correlation, the study has express the influenced from variation of soil porosity under fluctuation of soil consolidation in the study. It has also expressed the growth rate of Shigella influenced by variation of micronutrients in the formation; experts will definitely fine this study useful in monitoring and evaluation of microbial transport in soil and water environment.
\end{abstract}

Keywords: Modeling; Porosity shigella Transport; Sand gravel formation

\section{Introduction}

The reaction from 1996 Amendments on Safe Drinking Water Act, including the U.S. Environmental Protection Agency (USEPA) that are the developer of Ground-Water Rule (GWR). This will always protect users of public ground-water supplies from viral contamination [1-6]. Due the fact that total coliform bacteria are normally applied an indicator of the possibility or probable existence of pathogenic contamination from microbial pathogens, several groundwater suppliers applied the absence of coliform as justification for not disinfecting source water. Despite the inherent complications related with the identification of viruses in water, disease epidemics have been attributed to specific episodes of viral pollution in ground water [3-7]. There has been a suggestion as viral indicators. Coliphages are a bacterial virus that is known to infect the coliform bacterial group. Most of these coliphages that are superficially similar to the enteric viruses, they are known to share symmetrical structures, morphologies, and sizes, they also have similar half-lives in natural waters [8-10]. Some coliphages, precisely infect "male" strains of Escherichia coli (E. coli), or "malespecific" coliphages, they are normally found in human feces, this has been identified in huge numbers in human wastewater [11].

- $\quad$ Outbreaks of viral etiology have been documented in waters that met coliform criteria for drinking purposes [12-16].

- Viruses may be considerably more resilient in the environment than coliforms $[17,18]$.

- $\quad$ The infectious dose of many viral diseases is considerably lower than that observed for enteric bacterial disease [19-21].

\section{Theoretical Backgrounds}

Nomenclature:

C $=$ Shigella Concentration

$\mathrm{A}(\mathrm{x})=$ void Ratio /Permeability of Soil

$\mathrm{B}(\mathrm{x})=$ Velocity of Flow 
$\mathrm{C}-\mathrm{n}-[\alpha 1 \mathrm{x}] \quad=$ void ratio of soil

$\mathrm{x} \quad=$ Depth

$\frac{d c}{d x}+A_{(x)} C_{d}+B_{(x)} C_{d}^{n}=0$

Transform the above Bernoulli's Equation to a linear first order DE gives:

$$
\begin{aligned}
& \frac{d k}{d x}+(1-n) k=(1-n) B_{(x)} \\
& \text { Let I.F }=\ell^{-}{ }^{\alpha x_{1 x}}
\end{aligned}
$$

Use I.F to Solve (2) above

Hence, the general Solution becomes:

$$
C_{d}^{1-n}=-\frac{B}{A}+C e^{-\alpha_{1} x}
$$

\section{Materials and Method}

Standard laboratory experiment where performed to monitor Shigella using the standard method for the experiment at different formation, the soil deposition of the strata were collected in sequences base on the structural deposition of the lithology at different locations, this samples collected at different location generated variations at different depths producing different Shigella concentration through column experiment, from the pressure flow at different strata, the experimental result were compared with the theoretical values for the validation of the model.

\section{Results and Discussion}

Results and discussion are presented in tables including

\begin{tabular}{|c|c|c|}
\hline Depth [M] & Predictive Values [Conc. Mg/L] & Experimental Values [Conc. $\mathrm{Mg} / \mathrm{L}]$ \\
\hline 3 & 0.030077637 & 0.03 \\
\hline 6 & 0.060155274 & 0.06 \\
\hline 9 & 0.090232911 & 0.09 \\
\hline 12 & 0.120310548 & 0.12 \\
\hline 15 & 0.150388185 & 0.15 \\
\hline 18 & 0.180465822 & 0.18 \\
\hline 21 & 0.210543459 & 0.21 \\
\hline 24 & 0.240621096 & 0.24 \\
\hline 27 & 0.270698733 & 0.27 \\
\hline 30 & 0.30077637 & 0.33 \\
\hline 33 & 0.330854007 & 0.33 \\
\hline 36 & 0.360931644 & 0.36 \\
\hline 39 & 0.391009281 & 0.39 \\
\hline 42 & 0.421086918 & 0.42 \\
\hline 45 & 0.451164555 & 0.45 \\
\hline 48 & 0.481242192 & 0.48 \\
\hline 51 & 0.511319829 & 0.51 \\
\hline 54 & 0.541397466 & 0.54 \\
\hline 57 & 0.571475103 & 0.57 \\
\hline 60 & 0.60155274 & 0.62 \\
\hline 63 & 0.631630377 & 0.63 \\
\hline 66 & 0.661708014 & 0.66 \\
\hline 69 & 0.691785651 & 0.69 \\
\hline 71 & 0.711837409 & 0.71 \\
\hline 74 & 0.741915046 & 0.74 \\
\hline 77 & 0.771992683 & 0.77 \\
\hline 80 & 0.80207032 & 0.84 \\
\hline 83 & 0.832147957 & 0.83 \\
\hline 86 & 0.862225594 & 0.86 \\
\hline 89 & 0.892303231 & 0.89 \\
\hline 90 & 0.90232911 & 0.93 \\
\hline
\end{tabular}
graphical representation for Shigella concentration (Tables 1-7).

Table1: Predictive and experimental values of shigella concentration at different depth. 
Table 2: Predictive and experimental values of shigella concentration at different depth.

\begin{tabular}{|c|c|c|}
\hline Depth [M] & Predictive Values [Conc. Mg/L] & Experimental Values [Conc. $\mathrm{Mg} / \mathrm{L}$ ] \\
\hline 3 & 0.024625489 & 0.0246 \\
\hline 6 & 0.049250977 & 0.0492 \\
\hline 9 & 0.073876466 & 0.0738 \\
\hline 12 & 0.098501954 & 0.0984 \\
\hline 15 & 0.123127443 & 0.123 \\
\hline 18 & 0.147752931 & 0.1476 \\
\hline 21 & 0.17237842 & 0.1722 \\
\hline 24 & 0.197003908 & 0.1968 \\
\hline 27 & 0.221629397 & 0.2214 \\
\hline 30 & 0.246254885 & 0.246 \\
\hline 33 & 0.270880374 & 0.2706 \\
\hline 36 & 0.295505862 & 0.2952 \\
\hline 39 & 0.320131351 & 0.3198 \\
\hline 42 & 0.344756839 & 0.3444 \\
\hline 45 & 0.369382328 & 0.369 \\
\hline 48 & 0.394007816 & 0.3936 \\
\hline 51 & 0.418633305 & 0.4182 \\
\hline 54 & 0.443258793 & 0.4428 \\
\hline 57 & 0.467884282 & 0.4674 \\
\hline 60 & 0.49250977 & 0.492 \\
\hline 63 & 0.517135259 & 0.5166 \\
\hline 66 & 0.541760747 & 0.5412 \\
\hline 69 & 0.566386236 & 0.5658 \\
\hline 71 & 0.582803228 & 0.5822 \\
\hline 74 & 0.607428717 & 0.6068 \\
\hline 77 & 0.632054205 & 0.6314 \\
\hline 80 & 0.656679694 & 0.656 \\
\hline 83 & 0.681305182 & 0.6806 \\
\hline 86 & 0.705930671 & 0.7052 \\
\hline 89 & 0.730556159 & 0.7298 \\
\hline 90 & 0.738764655 & 0.738 \\
\hline
\end{tabular}

Table 3: Predictive and experimental values of shigella concentration at different depth.

\begin{tabular}{|c|c|c|}
\hline Depth [M] & Predictive Values [Conc. Mg/L] & 0.0201 \\
\hline 3 & 0.020161645 & 0.0402 \\
\hline 6 & 0.04032329 & 0.0603 \\
\hline 9 & 0.060484934 & 0.0804 \\
\hline 12 & 0.080646579 & 0.1005 \\
\hline 15 & 0.100808224 & 0.1206 \\
\hline 18 & 0.120969869 & 0.1407 \\
\hline 21 & 0.141131513 & 0.1608 \\
\hline 24 & 0.161293158 & 0.1809 \\
\hline 27 & 0.181454803 & 0.201 \\
\hline 30 & 0.201616448 & 0.2211 \\
\hline 33 & 0.221778092 & 0.2412 \\
\hline 36 & 0.241939737 & 0.2613 \\
\hline 39 & 0.262101382 & 0.2814 \\
\hline 42 & 0.282263027 & 0.3015 \\
\hline 48 & 0.302424671 & 0.3216 \\
\hline
\end{tabular}




\begin{tabular}{|c|c|c|}
\hline 51 & 0.342747961 & 0.3417 \\
\hline 54 & 0.362909606 & 0.3618 \\
\hline 57 & 0.38307125 & 0.3819 \\
\hline 60 & 0.403232895 & 0.402 \\
\hline 63 & 0.42339454 & 0.4422 \\
\hline 66 & 0.443556185 & 0.4623 \\
\hline 69 & 0.463717829 & 0.4757 \\
\hline 71 & 0.477158926 & 0.4958 \\
\hline 74 & 0.497320571 & 0.5159 \\
\hline 77 & 0.517482215 & 0.536 \\
\hline 80 & 0.53764386 & 0.5561 \\
\hline 86 & 0.557805505 & 0.5762 \\
\hline 90 & 0.57796715 & 0.5963 \\
\hline
\end{tabular}

Table 4: Predictive and experimental values of shigella concentration at different depth.

\begin{tabular}{|c|c|c|}
\hline Depth [M] & Predictive Values [Conc. Mg/L] & Experimental Values [Conc. $\mathrm{Mg} / \mathrm{L}$ ] \\
\hline 3 & 0.014936114 & 0.015 \\
\hline 6 & 0.029872228 & 0.032 \\
\hline 9 & 0.044808341 & 0.045 \\
\hline 12 & 0.059744455 & 0.065 \\
\hline 15 & 0.074680569 & 0.075 \\
\hline 18 & 0.089616683 & 0.093 \\
\hline 21 & 0.104552797 & 0.105 \\
\hline 24 & 0.11948891 & 0.122 \\
\hline 27 & 0.134425024 & 0.135 \\
\hline 30 & 0.149361138 & 0.155 \\
\hline 33 & 0.164297252 & 0.165 \\
\hline 36 & 0.179233365 & 0.183 \\
\hline 39 & 0.194169479 & 0.195 \\
\hline 42 & 0.209105593 & 0.212 \\
\hline 45 & 0.224041707 & 0.225 \\
\hline 48 & 0.238977821 & 0.243 \\
\hline 51 & 0.253913934 & 0.255 \\
\hline 54 & 0.268850048 & 0.275 \\
\hline 57 & 0.283786162 & 0.285 \\
\hline 60 & 0.298722276 & 0.322 \\
\hline 63 & 0.31365839 & 0.315 \\
\hline 66 & 0.328594503 & 0.333 \\
\hline 69 & 0.343530617 & 0.345 \\
\hline 71 & 0.353488026 & 0.355 \\
\hline 74 & 0.36842414 & 0.374 \\
\hline 77 & 0.383360254 & 0.385 \\
\hline 80 & 0.398296368 & 0.423 \\
\hline 83 & 0.413232481 & 0.415 \\
\hline 86 & 0.428168595 & 0.435 \\
\hline 89 & 0.443104709 & 0.445 \\
\hline 90 & 0.448083414 & 0.455 \\
\hline
\end{tabular}


Table 5: Predictive and experimental values of shigella concentration at different depth.

\begin{tabular}{|c|c|c|}
\hline Depth [M] & Predictive Values [Conc. $\mathrm{Mg} / \mathrm{L}$ ] & Experimental Values [Conc. Mg/L] \\
\hline 3 & 0.009059211 & 0.009 \\
\hline 6 & 0.018118422 & 0.018 \\
\hline 9 & 0.027177633 & 0.027 \\
\hline 12 & 0.036236844 & 0.036 \\
\hline 15 & 0.045296055 & 0.045 \\
\hline 18 & 0.054355266 & 0.054 \\
\hline 21 & 0.063414477 & 0.063 \\
\hline 24 & 0.072473688 & 0.072 \\
\hline 27 & 0.081532899 & 0.081 \\
\hline 30 & 0.090592109 & 0.091 \\
\hline 33 & 0.09965132 & 0.099 \\
\hline 36 & 0.108710531 & 0.108 \\
\hline 39 & 0.117769742 & 0.117 \\
\hline 42 & 0.126828953 & 0.126 \\
\hline 45 & 0.135888164 & 0.135 \\
\hline 48 & 0.144947375 & 0.144 \\
\hline 51 & 0.154006586 & 0.153 \\
\hline 54 & 0.163065797 & 0.162 \\
\hline 57 & 0.172125008 & 0.171 \\
\hline 60 & 0.181184219 & 0.182 \\
\hline 63 & 0.19024343 & 0.189 \\
\hline 66 & 0.199302641 & 0.198 \\
\hline 69 & 0.208361852 & 0.207 \\
\hline 71 & 0.214401326 & 0.213 \\
\hline 74 & 0.223460537 & 0.222 \\
\hline 77 & 0.232519748 & 0.231 \\
\hline 80 & 0.241578959 & 0.242 \\
\hline 83 & 0.25063817 & 0.249 \\
\hline 86 & 0.259697381 & 0.258 \\
\hline 89 & 0.268756591 & 0.267 \\
\hline 90 & 0.271776328 & 0.275 \\
\hline
\end{tabular}

Table 6: Predictive and experimental values of shigella concentration at different depth.

\begin{tabular}{|c|c|c|}
\hline Depth [M] & Predictive Values [Conc. Mg/L] & Experimental Values [Conc. Mg/L] \\
\hline 3 & 0.005494689 & 0.0054 \\
\hline 6 & 0.010989378 & 0.0108 \\
\hline 9 & 0.016484068 & 0.02162 \\
\hline 12 & 0.021978757 & 0.0273 \\
\hline 15 & 0.027473446 & 0.0324 \\
\hline 18 & 0.032968135 & 0.0378 \\
\hline 21 & 0.038462824 & 0.0432 \\
\hline 24 & 0.043957514 & 0.0486 \\
\hline 27 & 0.049452203 & 0.0542 \\
\hline 30 & 0.054946892 & 0.0594 \\
\hline 33 & 0.060441581 & 0.0648 \\
\hline 36 & 0.06593627 & 0.0702 \\
\hline 39 & 0.07143096 & 0.0756 \\
\hline 42 & 0.076925649 & 0.0812 \\
\hline 45 & 0.082420338 & 0.0864 \\
\hline
\end{tabular}




\begin{tabular}{|c|l|l|}
\hline 51 & 0.093409716 & 0.0918 \\
\hline 54 & 0.098904406 & 0.0972 \\
\hline 57 & 0.104399095 & 0.1026 \\
\hline 60 & 0.109893784 & 0.1082 \\
\hline 63 & 0.115388473 & 0.1134 \\
\hline 66 & 0.120883162 & 0.1242 \\
\hline 69 & 0.126377851 & 0.1278 \\
\hline 71 & 0.130040978 & 0.1332 \\
\hline 74 & 0.135535667 & 0.1386 \\
\hline 77 & 0.141030356 & 0.1443 \\
\hline 80 & 0.146525045 & 0.1494 \\
\hline 86 & 0.152019734 & 0.1548 \\
\hline 90 & 0.157514424 & 0.1602 \\
\hline
\end{tabular}

Table 7: Variation of shigella concentration at different depth.

\begin{tabular}{|c|c|c|c|c|c|c|}
\hline Soil porosity & 0.23 & 0.25 & 0.27 & 0.3 & 0.35 & 0.4 \\
\hline $3 \mathrm{~m}$ & 0.03008 & 0.02463 & 0.02016 & 0.01494 & 0.00906 & 0.00549 \\
\hline $6 \mathrm{~m}$ & 0.06016 & 0.04925 & 0.04032 & 0.02987 & 0.01812 & 0.01099 \\
\hline $9 \mathrm{~m}$ & 0.09023 & 0.07388 & 0.06048 & 0.04481 & 0.02718 & 0.01648 \\
\hline $12 \mathrm{~m}$ & 0.12031 & 0.0985 & 0.08065 & 0.05974 & 0.03624 & 0.02198 \\
\hline $15 \mathrm{~m}$ & 0.15039 & 0.12313 & 0.10081 & 0.07468 & 0.0453 & 0.02747 \\
\hline $18 \mathrm{~m}$ & 0.18047 & 0.14775 & 0.12097 & 0.08962 & 0.05436 & 0.03297 \\
\hline $21 \mathrm{~m}$ & 0.21054 & 0.17238 & 0.14113 & 0.10455 & 0.06341 & 0.03846 \\
\hline $24 \mathrm{~m}$ & 0.24062 & 0.197 & 0.16129 & 0.11949 & 0.07247 & 0.04396 \\
\hline $27 \mathrm{~m}$ & 0.2707 & 0.22163 & 0.18145 & 0.13443 & 0.08153 & 0.04945 \\
\hline $30 \mathrm{~m}$ & 0.30078 & 0.24625 & 0.20162 & 0.14936 & 0.09059 & 0.05495 \\
\hline $33 \mathrm{~m}$ & 0.33085 & 0.27088 & 0.22178 & 0.1643 & 0.09965 & 0.06044 \\
\hline $36 \mathrm{~m}$ & 0.36093 & 0.29551 & 0.24194 & 0.17923 & 0.10871 & 0.06594 \\
\hline $39 \mathrm{~m}$ & 0.39101 & 0.32013 & 0.2621 & 0.19417 & 0.11777 & 0.07143 \\
\hline $42 \mathrm{~m}$ & 0.42109 & 0.34476 & 0.28226 & 0.20911 & 0.12683 & 0.07693 \\
\hline $45 \mathrm{~m}$ & 0.45116 & 0.36938 & 0.30242 & 0.22404 & 0.13589 & 0.08242 \\
\hline $48 \mathrm{~m}$ & 0.48124 & 0.39401 & 0.32259 & 0.23898 & 0.14495 & 0.08792 \\
\hline $51 \mathrm{~m}$ & 0.51132 & 0.41863 & 0.34275 & 0.25391 & 0.15401 & 0.09341 \\
\hline $54 \mathrm{~m}$ & 0.5414 & 0.44326 & 0.36291 & 0.26885 & 0.16307 & 0.0989 \\
\hline $57 \mathrm{~m}$ & 0.57148 & 0.46788 & 0.38307 & 0.28379 & 0.17213 & 0.1044 \\
\hline $60 \mathrm{~m}$ & 0.60155 & 0.49251 & 0.40323 & 0.29872 & 0.18118 & 0.10989 \\
\hline $63 \mathrm{~m}$ & 0.63163 & 0.51714 & 0.42339 & 0.31366 & 0.19024 & 0.11539 \\
\hline $66 \mathrm{~m}$ & 0.66171 & 0.54176 & 0.44356 & 0.32859 & 0.1993 & 0.12088 \\
\hline $69 \mathrm{~m}$ & 0.69179 & 0.56639 & 0.46372 & 0.34353 & 0.20836 & 0.12638 \\
\hline $71 \mathrm{~m}$ & 0.71184 & 0.5828 & 0.47716 & 0.35349 & 0.2144 & 0.13004 \\
\hline $74 \mathrm{~m}$ & 0.74192 & 0.60743 & 0.49732 & 0.36842 & 0.22346 & 0.13554 \\
\hline $77 \mathrm{~m}$ & 0.77199 & 0.63205 & 0.51748 & 0.38336 & 0.23252 & 0.14103 \\
\hline $80 \mathrm{~m}$ & 0.80207 & 0.65668 & 0.53764 & 0.3983 & 0.24158 & 0.14653 \\
\hline $83 \mathrm{~m}$ & 0.83215 & 0.68131 & 0.55781 & 0.41323 & 0.25064 & 0.15202 \\
\hline $86 \mathrm{~m}$ & 0.86223 & 0.70593 & 0.57797 & 0.42817 & 0.2597 & 0.15751 \\
\hline $89 m$ & 0.8923 & 0.73056 & 0.59813 & 0.4431 & 0.26876 & 0.16301 \\
\hline $90 \mathrm{~m}$ & 0.90233 & 0.73876 & 0.60485 & 0.44808 & 0.27178 & 0.16484 \\
\hline
\end{tabular}


Figures 1-7 explain the behavior of the system in terms of growth rate of Shigella in heterogeneous grave depositions, the figures experienced linear trend under exponential condition, the transport of the microbes observed increase with respect to depth, but the concentration were observed in different rates, the simulation express the behavior of Shigella migration in gravel deposition, these condition were expressed from various figures as it explained the influence of heterogeneous structure of the formation to be insignificant from the observed effect on the rate of concentration, because it express linear growth rate to the optimum depth, increase in concentration with respect to increase in depth were observed from all the figures, the experimental values compared favorably well with the predictive values, the optimum rate of concentration recorded at ninety meters, but the rate of concentration varies based on the porosity depositions of gravel in the study location, figure seven observed the rate of porosity variation with respect to variation of concentration in different depositions and locations, the figure experienced consolidation of porosity variation in the lithe structures of the formation, thus the concentration observed increase at high consolidation of the porosity, but suddenly decrease in concentration were it experienced decrease in consolidation thus high increase in porosity of the formation. The figure explained the influenced from soil porosity in various deposition of the formation.

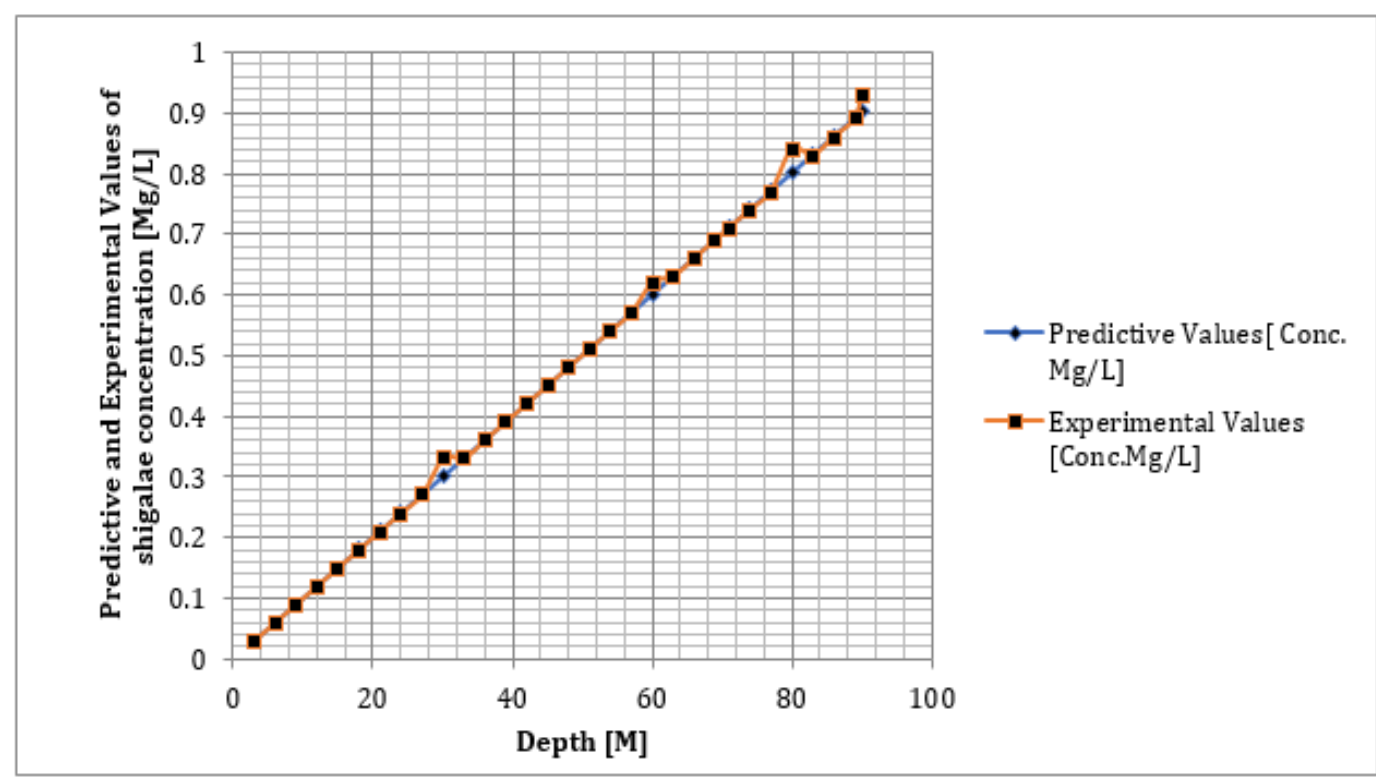

Figure 1: Predictive and experimental values of shigella concentration at different depth.

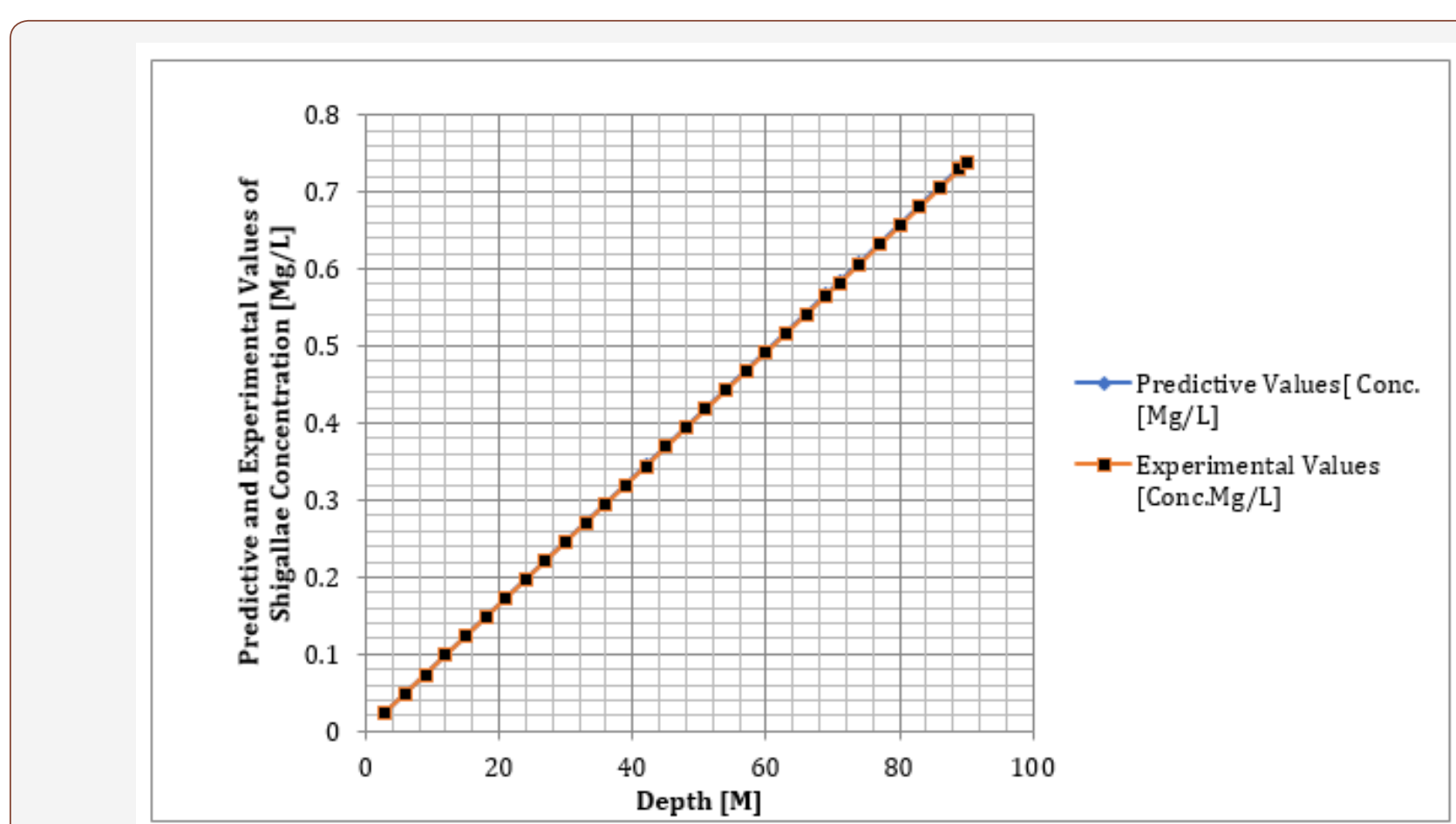

Figure 2: Predictive and experimental values of shigella concentration at different depth. 


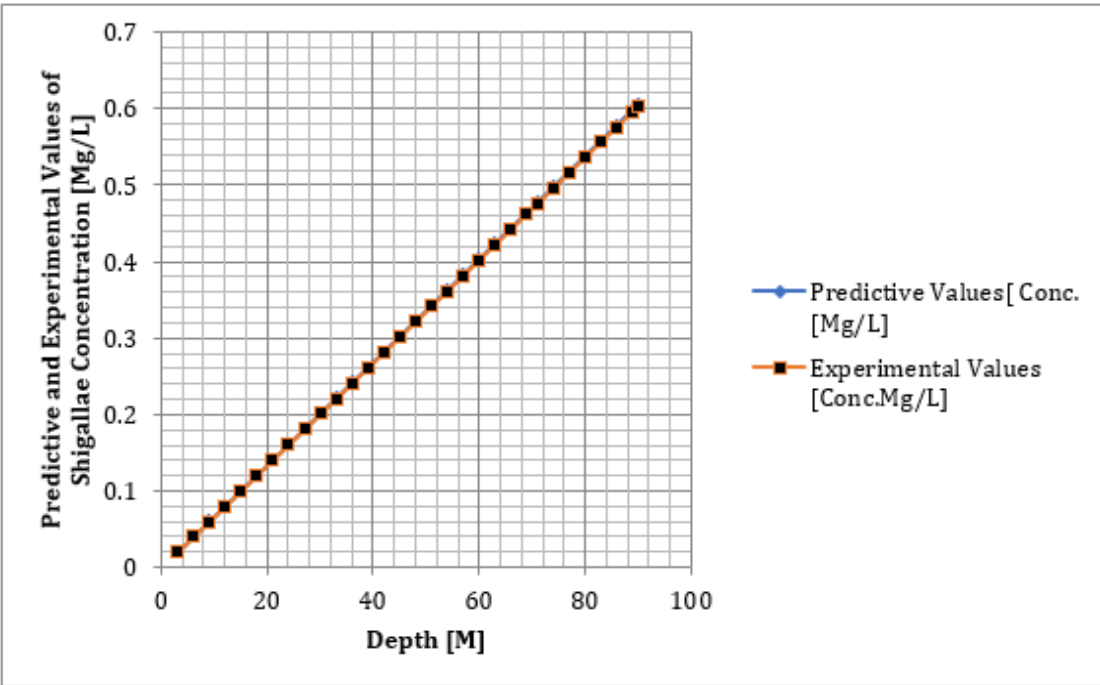

Figure 3: Predictive and experimental values of shigella concentration at different depth.

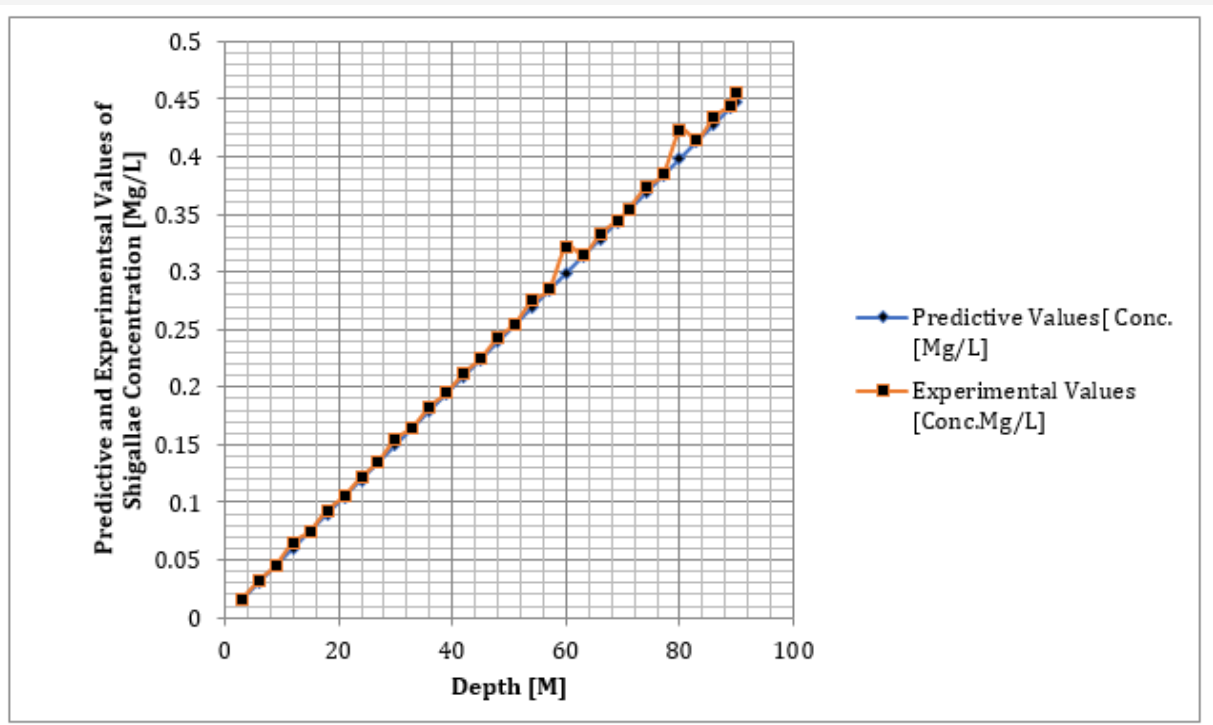

Figure 4: Predictive and experimental values of shigella concentration at different depth.

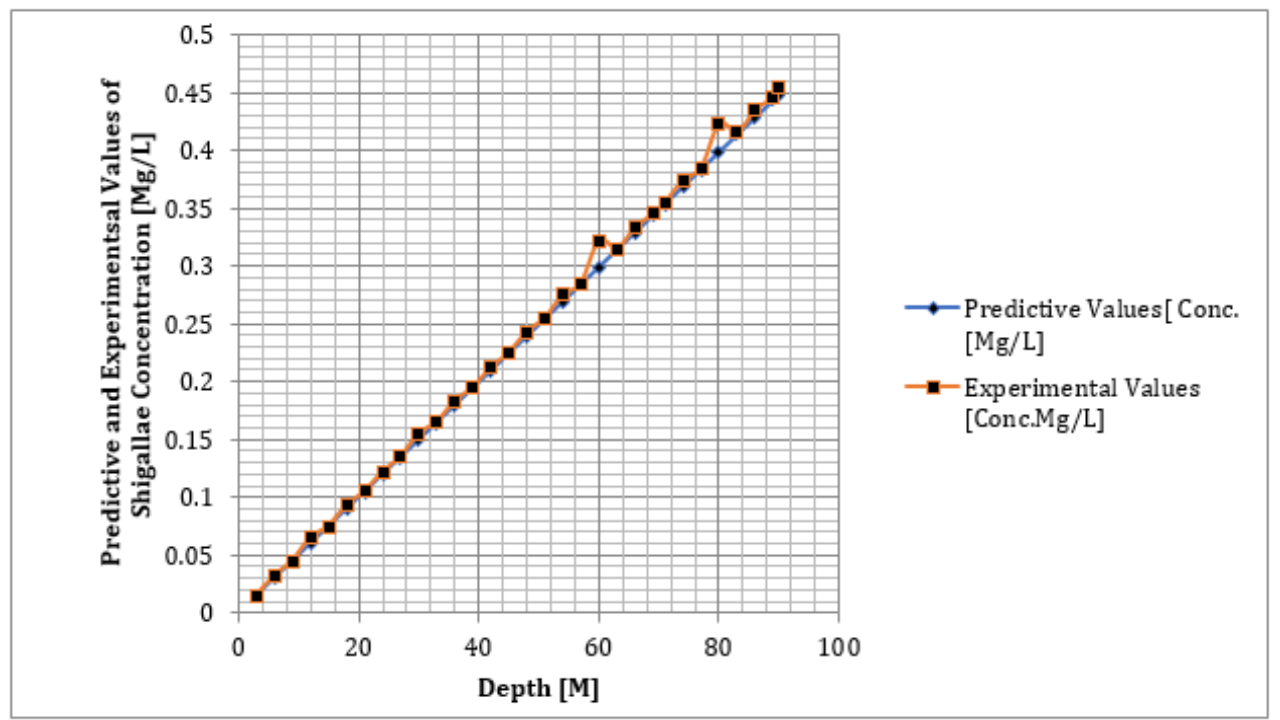

Figure 5: Predictive and experimental values of shigella concentration at different depth. 


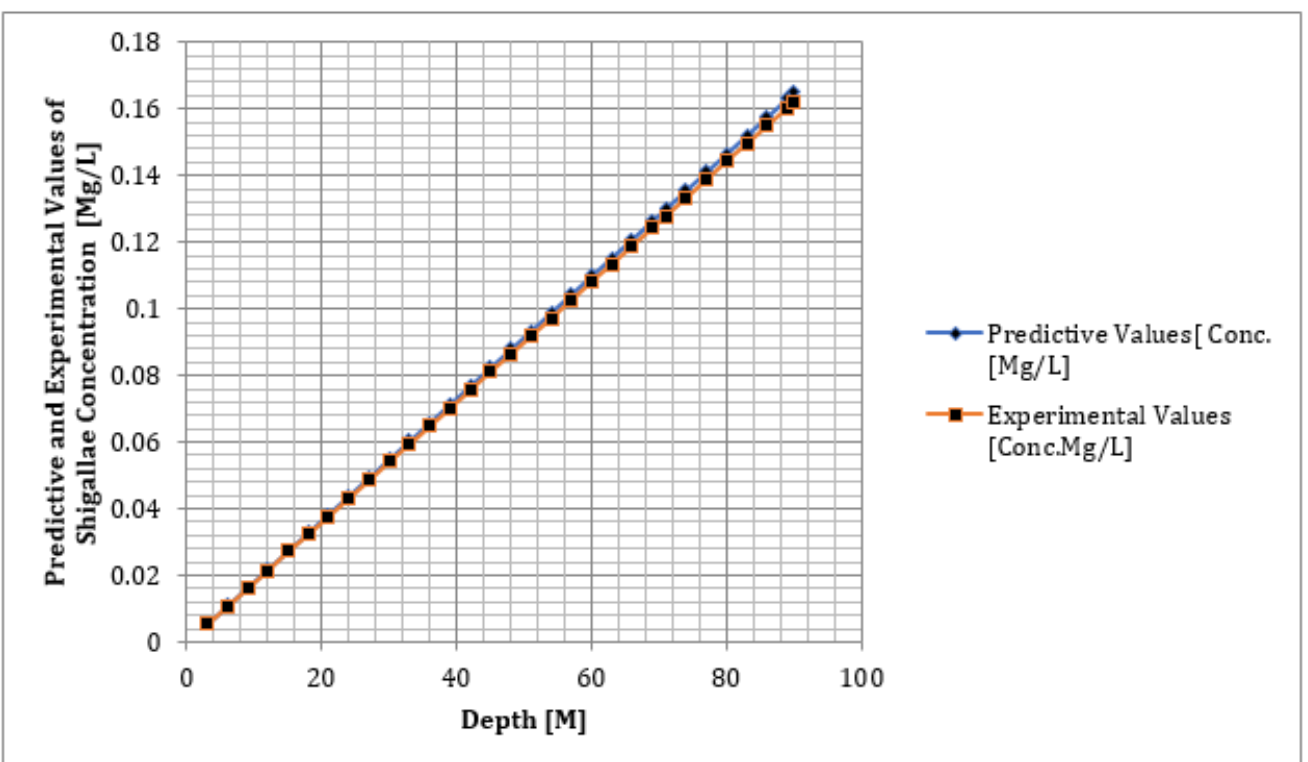

Figure 6: Predictive and experimental values of shigella concentration at different depth.

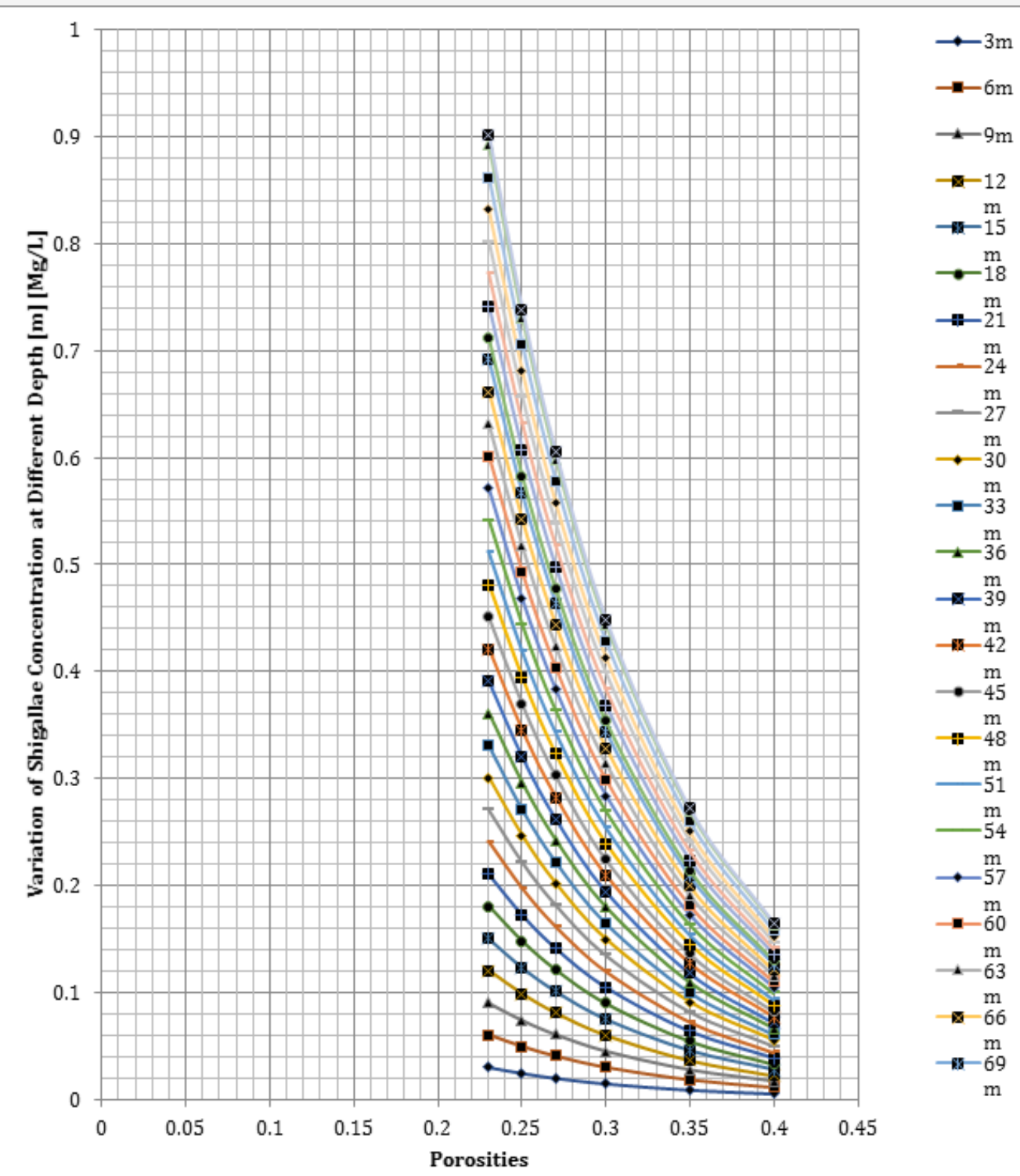

Figure 7: Variation of predictive values of Shigella concentration influenced by depositions of the formations. 


\section{Conclusion}

The study expresses the effect of porosities in various depositions of gravel, the transport of Shigella were monitored to determine the effect of porosity on the deposition and transport of the microbes in such heterogeneous gravel formation. The study expresses the variation of soil porosity in different condition monitored in the system, the transport rate was from three to ninety meters depth, linear trend was observed in the study, but with different concentration. Monitoring the effect of porosity on the migration of Shigella on variation of porosity with respect to concentration is based on the rate of the formation consolidation. decrease in soil porosity generated higher concentration at three meters, but when the porosity of the soil experienced decrease in it consolidation thus high porosity, decrease in concentration were observed, despite exponential growth rate were the optimum concentration were recorded at ninety meters, when the concentration were monitored in terms of variation influences of porosity, the concentration experienced lower concentration recorded at [0.40] while the highest concentration were observed at porosity rate of [0.23] these has explained the behavior of the transport in two dimension increase in concentration based on increase in depth, this could be attribute to deposition of micronutrients, while high to low concentration are based on the influences from variation of soil porosity in gravel depositions. The study has expressed the behavior of Shigella in terms of transport were micronutrient are deposited, it has also explained the influenced from variation of soil porosity in Shigella depositions on gravel formations.

\section{Acknowledgement}

None.

\section{Conflict of Interest}

No conflict of interest.

\section{References}

1. U.S. Environmental Protection Agency (2001a) Ambient water-quality criteria for bacteria-1986: Washington, D.C., Office of Water Regulation and Standards, $17 \mathrm{p}$.

2. Eluozo SN, Nwaoburu AO (2013) Mathematical Model to Monitor the deposition of Void ratio and Dispersion of Phosphorous Influenced in salmonella Growth Rate in Coarse and Gravel Formation in Borikiri, Rivers State of Nigeria. American Journal of Engineering Science and Technology Research 1(4): 59-67.

3. Eluozo SN, Nwaoburu AO (2013) Mathematical Model to Predict Adsorption Rate of Potassium Influenced by Permeability in Lateritic and Silty Formation in Coastal Area of Eagle Island, Port Harcourt, Niger Delta of Nigeria. International Journal Sustainable Energy and Environment 1(5): 111-119.

4. Eluozo SN, Nwaoburu AO (2013) Modeling the Deposition Adsorption Rate of Carbon Influenced by Porosity in Semi Confined Bed in Okirika, Rivers State of Nigeria. International Journal of sustainable Energy and Environment 1(5): 103-110.

5. Eluozo SN, Nwaoburu AO (2013) Mathematical Model to Predict the Migration of Cryptosporidium in Homogeneous Formation in Obio-
Akpor, Rivers State of Nigeria. International Journal Applied Chemical Science Research 1(6): 83-94.

6. Eluozo SN, Nwaoburu AO (2013) Modeling the Transport of Arsenic on Pore Fluid and Solid Surface in Heterogeneous Soil Formation, Niger Delta of Nigeria. World Journal of Science and Technology Research 1(6): 124-134.

7. Craun GF, Mc Cabe LJ, Hughes JM (1976) Waterborne disease outbreaks in the US-1971-1974: Journal of the American Water Works Association 68: 420-424.

8. Hejkal TW, Keswick B, La Belle RL, Gerba CP, Sanchez Y, et al. (1982) Viruses in a community water supply associated with an outbreak of gastroenteritis and infectious hepatitis: Journal of the American Water Works Association 74(6): 318-321.

9. Herwaldt BL, Craun GF, Stokes SL, Juranek DD (1992) M \& O outbreaks of waterborne disease in the United States 1989-1990: Journal of the American Water Works Association 84(4): 129-134.

10. Divizia M, Gnesivo C, Bonapasta RA, Morace G, Pisani G, et al. (1993) Virus isolation and identification by PCR in an outbreak of hepatitis A: Epidemiological investigation: Water Science Technology 3(4): 199-203.

11. Beller M, Ellis A, Lee SH, Drebot MA (1997) Outbreak of viral gastroenteritis due to a contaminated well: International consequences: Journal of the American Medical Association 278(7): 563-568.

12. Eluozo SN (2013) Effect of formation characteristics on hydraulic conductivity in unconfined bed in Etche Rivers State of Nigeria: Scientific Journal of Pure and Applied Science 2(1): 2322-2956.

13. Eluozo SN, Ademiluyi JO, Nwaoburu AO (2011) Model Development Approach to Predict the Behaviour of E. coli Transport on Stationary Phase in Khana, Deltaic Environment of Rivers State, Nigeria. International Journal of Current Research 3(7): 140-145.

14. Eluozo SN (2012) Mathematical Model to Predict Klebsiella Pneumonae Transport influenced by Porosity and Void Ratio in Shallow Aquifers. ARPN Journal of Earth Science 1(2): 1-5.

15. Havelaar AH (1986) F-specific RNA bacteriophages as model viruses in water treatment processes: Bilthoven, The Netherlands, Rijksinstituut voor Volksgezondheid, Milieuhgyiene, Ph.D dissertation-A Havelaar, $462 \mathrm{p}$

16. Kukkula M, Maunula L, Silvennoinen E, Von Bonsdorff C (1999) Outbreak of viral gastroenteritis due to drinking water contaminated by Norwalklike viruses: Journal of Infectious Diseases 180(6): 1771-1776.

17. Eluozo SN, Ademiluyi JO (2013) Establishment of Porosity and Permeability Model Correlation to Validate E. coli Transport to Groundwater Aquifers; Rivers State of Nigeria; International Journal of Engineering and Technology, Science Publishing Corporation 2(1): $17-$ 24.

18. Eluozo SN (2013) Dispersion influence from Void Ratio and Porosity on E. coli Transport in Homogeneous Formation in Coastal Area of Degema, Rivers State of Nigeria: Scientific Journal of Environmental Science 2(1): $10-18$

19. Eluozo SN, Nwaoburu AO (2013) Mathematical Model to Predict Transient Flow Influenced by Compressible Fluid in Non-Homogeneous Anisotropic Aquifer in Deltaic Environment. Sjournals: Engineering Science and Technology, pp. 1-9.

20. Eluozo SN, Nwaoburu AO (2013) Mathematical Modeling and Simulation to Predict the transport of Diplococcic in Homogeneous Unconfined Aquifer in Port Harcourt Metropolis, Niger delta of Nigeria International Journal of Materials, Methods and Technology 1(5): 103-115.

21. Eluozo SN, Nwaoburu, AO (2013) Model Evaluation to Predict Nitrogen Depositions influenced by Porosity and Cadmium Inhibition in Coastal area of Port Harcourt. American Journal of Engineering Science and Technology Research 1(8): 128-140. 